УДК 004.8

DOI https://doi.org/10.32838/2663-5941/2020.4/17

Савчук T.O.

Вінницький національний технічний університет

Ваховський В.М.

Вінницький національний технічний університет

\title{
УДОСКОНАЛЕНИЙ МЕТОД АНАЛІЗУ ФОНДОВОГО РИНКУ АКЦІЙ ІЗ ВИКОРИСТАННЯМ НЕЧІТКОЇ ЛОГІКИ
}

У статті розглянуто найбільш поширені методи аналізу фондового ринку акиій та визначено їх основні переваги та недоліки. Основним недоліком цих методів можна вважсати низький рівень їх аналітичної точності, що робить їх малоефективними для використання. Визначено, що нечітка логіка має потенціал для покращення продукиійного методу аналізу фондового ринку акиій.

У статті було запропоновано удосконалений метод аналізу фондового ринку акцій, який створений на основі продукиійного методу аналізу фондового ринку акиій із використанням елементів нечіткої логіки. Цей метод дає змогу підвищити ефективність аналізу фондового ринку акиій завдяки використанню показників, що складно формалізуються, за допомогою введення нечітких множин, функиій належності, лінгвістичних змінних, терм-множин, нечіткої імплікації та ступеня істинності що своєю чергою сприяє підвищенню рівня точності аналізу, а також зростанню ступеня автоматизачії вирішення конфліктних ситуачій під час аналізу, ще відкидає постійну потребу втручання користувача та сприяє формуванню обтрунтованих висновків щуодо тенденції зміни иін на фондовому ринку акцій.

У статті було проведено дослідження ефективності вдосконаленого методу аналізу фондового ринку акиій, яке показало, що ией метод дав змогу врахувати нові показники, що складно формалізуються, серед яких: рівень доходів населення, рівень інфляиії, продуктивність прачі, рівень податкових ставок, ліквідність активів, кредитний ризик, демографія інвесторів, стан макроекономіки та інші. У результаті порівняння удосконаленого та продукиійного методів аналізу фондового ринку акиій (на основі семи різних галузей аналізу) виявлено, що використання запропонованого вдосконаленого методу аналізу фондового ринку акиій у середньому збільшує точність такого аналізу на 8,9\%.

Ключові слова: фондовий ринок акиій, нечітка логіка, метод аналізу фондового ринку акиій, інтелектуальний аналіз даних, нечітка імплікація.

Постановка проблеми. В останні роки зростання кількості учасників на фондовому ринку акцій призвело до збільшення ролі фондового ринку акцій як інструменту фінансування та розвитку економіки. Через це на фондовому ринку акцій збільшився також кругообіг капіталу, в одних галузях створюються значні запаси, а інші потребують значних фінансових вкладень для нормального функціонування.

Фондовий ринок акцій - це частина ринку капіталів, де здійснюються емісія, купівля і продаж акцій, що включає в себе окремі взаємопов'язані елементи [1].

Аналіз фондового ринку акцій - комплекс дій, спрямованих на вивчення усіх факторів, умов, ситуацій, які впливають на фондовий ринок акцій, що має за мету визначення тенденції розвитку цін на фондовому ринку акцій [1].

Нині найбільшого поширення набули нейромережевий та продукційний метод.
Нейромережевий метод аналізу фондового ринку акцій заснований на математичному моделюванні функціонування нейронів. Його методологія побудова систем, подібних до нейронів головного мозку [2]. До переваг цього методу можна зарахувати змогу обробляти неповні дані та відсутність необхідності формалізації знань. На практиці ж нейронні мережі, принаймні, реалізовані в стандартних програмних пакетах для аналізу фондового ринку акцій, мають досить низьку аналітичну ефективність через труднощі інтерпретації результатів роботи нейронної мережі і пояснень, чому вона прийняла те чи інше рішення [3].

Продукційний метод аналізу фондового ринку акцій передбачає математичне моделювання свідомої діяльності людини, тобто виявлення i застосування в інтелектуальній системі для аналізу фондового ринку акцій різних евристик, які використовуються для вирішення задачі аналізу фондового ринку акцій [4]. Цей метод здатен 
забезпечувати вищий рівень точності порівняно 3 нейромережевим методом завдяки своїй простоті, наочності, високій модульності та легкості до внесення змін. Проте він має проблеми із врахуванням економічних показників, які складно формалізуються, а також потребує постійного втручання користувача через високий рівень конфліктних ситуацій, що своєю чергою негативно впливає на точність аналізу [4].

Сучасні методи аналізу фондового ринку акції характеризуються недостатнім рівнем точності. Нейромережевий метод має низку потенційних переваг, але й досить серйозні недоліки. Наприклад, відсутність безперервного перенавчання нейромережі в процесі виконання завдання досить швидко робить iii неефективною в аналізі ситуації на ринку. Продукційний метод дає змогу прослідкувати за всім процесом аналізу фондового ринку акцій, $є$ ефективним та легко інтерпретується, але він не забезпечує необхідного рівня точності [5]. Тому актуальною задачею $є$ вдосконалення продукційного методу шляхом використання нечіткої логіки, що дасть змогу враховувати економічні показники, які складно формалізуються. Це своєю чергою сприяє підвищенню рівня точності аналізу фондового ринку акцій.

Аналіз останніх досліджень i публікацій. Наявні методи аналізу фондового ринку виконують поставлене завдання 3 недостатнім рівнем точності, не враховують певних показників, що складно формалізуються, що своєю чергою знижує рівень їх точності. Питання аналізу фондового ринку досліджувалося в роботах таких науковців, як Т.Б. Бердникова, В.Г. Руденко та О.Д. Штанько [2-4]. Водночас невирішеним залишається питання, пов'язане з усуненням конфліктних ситуацій, що дало б змогу значно підвищити точність аналізу, а також автоматизувати процес аналізу фондового ринку акцій.

Постановка завдання. Метою дослідження $\epsilon$ удосконалення продукційного методу аналізу фондового ринку акцій за допомогою використання нечіткої логіки, що значно підвищить точність аналізу фондового ринку.

Виклад основного матеріалу дослідження. Загалом аналіз фондового ринку акцій включає низку показників, що складно формалізуються, до них можна зарахувати рівень доходів населення, рівень інфляції, рівень податкових ставок, рівень капіталовкладень та інші, точність яких може бути підвищена шляхом застосування теорії нечітких множин [6].

Удосконалений метод аналізу фондового ринку акцій має відповідати таким функціональним вимогам [7]:
- змога визначити ступінь істинності входів та виходів кожної з нечітких множин для аналізу фондового ринку акцій;

- здатність автоматично вирішити конфліктні ситуації, що виникають при аналізі фондового ринку акцій;

- змога обчислювати правила аналізу фондового ринку акцій на основі використання нечітких операторів та застосовувати імплікацію для отримання вихідних значень відповідних правил;

- здатність формувати висновки щодо фондового ринку акцій із високим рівнем точності.

Класичний продукційний метод аналізу фонду ринку акцій передбачає такі основні кроки: підготовка інформації для аналізу, подання інформації щодо показників, вирішення конфліктів у правилах, що мають суперечливості, формування висновку щодо тенденції зміни цін акцій. Розглянемо доцільність використання нечіткої логіки в частині введення нечіткості показників в означеному методі аналізу.

Удосконалений метод аналізу фондового ринку з використанням нечіткої логіки складається з таких етапів: підготовка інформації для аналізу, подання інформації щодо показників, введення нечіткості показників, знаходження ступеня істинності умов та висновків, вирішення конфліктів у правилах, що мають суперечливості, формування висновку щодо тенденції зміни цін акцій (рисунок 1).

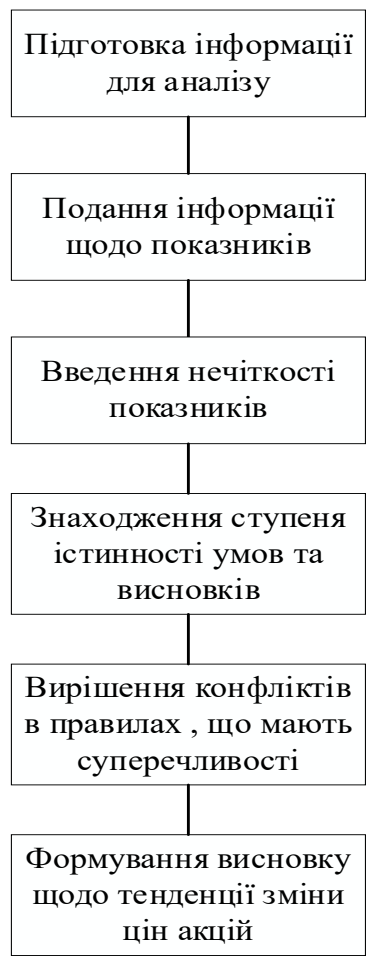

Рис. 1. Основні етапи вдосконаленого методу аналізу фондового ринку акцій 


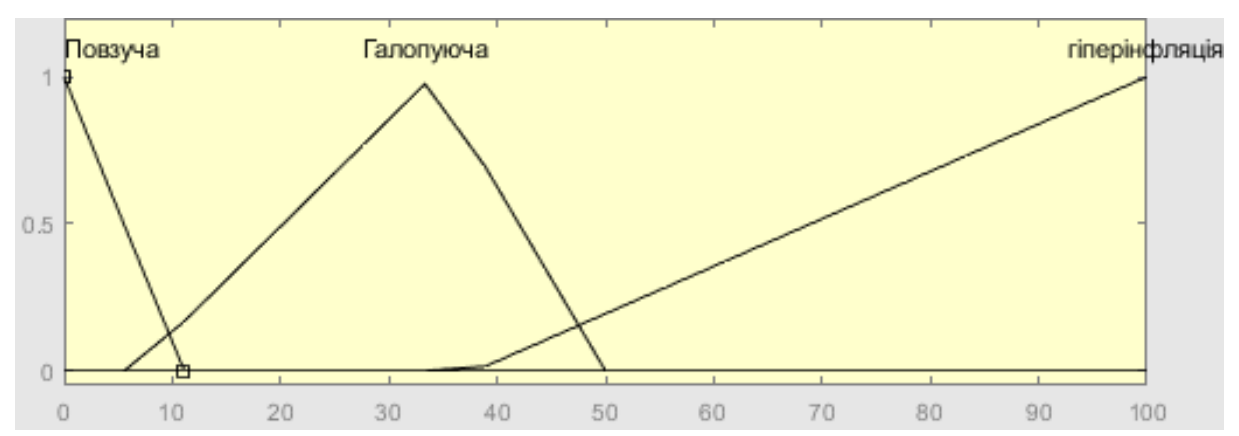

Рис. 2. Функція належності показника рівень інфляції

На етапі підготовки інформації за визначеними параметрами відбувається формування бази правил аналізу фондового ринку акцій у форматі "if - then". База правил для аналізу фондового ринку акцій має відповідати низці вимог:

- для будь-якого терму вхідної змінної аналізу фондового ринку акцій має існувати хоча б одне правило, в якому цей терм використовується в лівій частині правила;

- має існувати хоча б одне правило аналізу фондовому ринку акцій для кожного лінгвістичного терму вихідної змінної;

- дотримання достовірності конкретних та узагальнених відомостей, наявних у базі даних;

На етапі подання інформації щодо показників фондового ринку акцій відбувається формалізація показників фондового ринку акцій. Наприклад, для формалізації рівня інфляції використаємо три терми [2]:

- повзуча інфляція (до $11 \%$ на рік);

- галопуюча інфляція (6-50\% на рік);

- гіперінфляція (38-10 000\% на рік).

Функція належності рівня інфляції зображена на рисунку 2.

На етапі введення нечіткості за допомогою функції належності відбувається перехід від чіткого значення деякого параметра до нечіткого значення, що використовується для аналізу фондового ринку акцій [4]. Наведемо приклад процесу введення нечіткості для показника рівень інфляції:

$$
\mathrm{x}_{1}=8 \text {, }
$$

де $\mathrm{x}_{1}$ - вхідна лінгвістична змінна рівень інфляції.

Тоді фактичне значення для визначення функції належності матиме вигляд:

$$
\mu_{A_{1}}(8),
$$

де $A_{1}$ - терм вхідної лінгвістичної змінної рівень інфляції.

На етапі визначення знаходження ступеня істинності умов та висновків відбувається:
1) задання ступенів істинності умов на основі відповідей 4 експертів [6]. Наприклад, задання ступеня істинності для показника рівень інфляції наведено в таблиці 1;

Таблиця 1

Задання ступеня істинності для показника

\begin{tabular}{|c|c|c|c|c|c|}
\hline Показник & 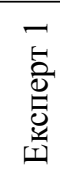 & 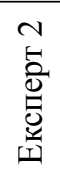 & 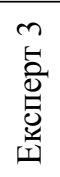 & 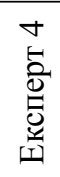 & 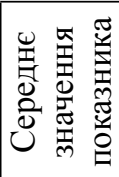 \\
\hline Рівень інфляції & 0,7 & 0,6 & 0,7 & 0,7 & 0,67 \\
\hline
\end{tabular}
рівень інфляції

2) знаходження ступенів істинності висновків кожного з правил нечітких продукцій аналізу фондового ринку акцій із використанням парних нечітких логічних операцій [4]. Наведемо приклад знаходження ступеня істинності висновку в правилі $з$ використанням показників рівень інфляції та рівень податкових ставок:

$$
C_{1}=\min \left(\mu_{A_{1}}, \mu_{B_{1}}\right),
$$

де $\propto_{A_{1}}, \propto_{A_{2}}-$ фактичні значення для визначення функцій належності показників рівень інфляції та рівень податкових ставок;

$C_{1}$ - терм функції належності вихідної лінгвістичної змінної.

На етапі вирішення конфліктів із правил, що потрапили до конфліктної множини, обирається лише одне, яке має вищий ступінь істинності. Наприклад, якщо при аналізі фондового ринку акцій 3'явилася змога застосувати одразу кілька правил, які мають суперечливості, то вони вносяться до конфліктної множини та після завершення формування конфліктної множини 3 них обирається лише одне.

На наступному етапі формується висновок та, у разі потреби, надаються покрокові пояснення щодо ситуації на фондовому ринку акцій. Для визначення рівня точності було обрано набори 
економічних показників у кожній із 7 різних галузей на фондовому ринку акцій:

- агропромислова;

- логістична;

- енергетична;

- нафтопереробна;

- металургійна;
- автомобільна;

- харчова.

Набори показників та галузей для дослідження методів аналізу були взяті з відкритих даних Української фондової біржі [8].

Кожен експеримент зводився до дослідження показників дохідності, ставки дисконтування

Таблиця 2

Результати дослідження показників фондового ринку акцій

\begin{tabular}{|c|c|c|c|c|}
\hline Галузь & Показник & $\begin{array}{c}\text { Дійсне } \\
\text { значення } \\
\text { показника }\end{array}$ & $\begin{array}{c}\text { Значення показника, } \\
\text { отримане } \\
\text { з використанням } \\
\text { продукційного методу }\end{array}$ & $\begin{array}{c}\text { Значення показника, } \\
\text { отримане } \\
\text { з використанням } \\
\text { удосконаленого методу }\end{array}$ \\
\hline 1 & 2 & 3 & 4 & 5 \\
\hline \multirow{3}{*}{ Агропромислова } & Дохідність, тис. грн & 9160 & 8235 & 8865 \\
\hline & Ставка дисконтування, \% & 14 & 13 & 13 \\
\hline & Галузевий ризик, \% & 24 & 22 & 25 \\
\hline \multirow{3}{*}{ Логістична } & Дохідність, тис. грн & 8540 & 8924 & 8538 \\
\hline & Ставка дисконтування, \% & 16 & 15 & 16,9 \\
\hline & Галузевий ризик, \% & 68 & 65,1 & 70,2 \\
\hline \multirow{3}{*}{ Енергетична } & Дохідність, тис. грн & 42632 & 41447 & 41710 \\
\hline & Ставка дисконтування, \% & 9,4 & 8,3 & 8,6 \\
\hline & Галузевий ризик, \% & 16,5 & 16,3 & 16,7 \\
\hline \multirow{3}{*}{ Нафтопереробна } & Дохідність, тис. грн & 67220 & 69250 & 66902 \\
\hline & Ставка дисконтування, \% & 11,8 & 14 & 12,4 \\
\hline & Галузевий ризик, \% & 14 & 13,5 & 14,4 \\
\hline \multirow{3}{*}{ Металургійна } & Дохідність, тис. грн & 52364 & 55232 & 54128 \\
\hline & Ставка дисконтування, \% & 15 & 15,8 & 15,7 \\
\hline & Галузевий ризик, \% & 10 & 9 & 9,6 \\
\hline \multirow{3}{*}{ Автомобільна } & Дохідність, тис. грн & 6265 & 7097 & 6824 \\
\hline & Ставка дисконтування, \% & 9 & 9 & 9 \\
\hline & Галузевий ризик, \% & 75 & 66 & 78 \\
\hline \multirow{3}{*}{ Харчова } & Дохідність, тис. грн & 6153 & 5893 & 6002 \\
\hline & Ставка дисконтування, \% & 14,2 & 14,1 & 15 \\
\hline & Галузевий ризик, \% & 58,9 & 64,5 & 60 \\
\hline
\end{tabular}

Таблиця 3

Відносне відхилення показників фондового ринку акцій досліджених галузей

\begin{tabular}{|l|l|c|c|c|}
\hline \multicolumn{1}{|c|}{ Галузь } & \multicolumn{1}{|c|}{$\begin{array}{c}\text { Відхилення } \\
\text { показника }\end{array}$} & $\begin{array}{c}\text { Дохідність, } \\
\mathbf{\%}\end{array}$ & $\begin{array}{c}\text { Ставка } \\
\text { дисконтування, \% }\end{array}$ & $\begin{array}{c}\text { Галузевий } \\
\text { ризик, \% }\end{array}$ \\
\hline \multirow{2}{*}{ Агропромислова } & Продукційний & 11,2 & 7,7 & 9 \\
\cline { 2 - 5 } & Удосконалений & 3,3 & 7,7 & 4 \\
\hline \multirow{2}{*}{ Логістична } & Продукційний & 4,3 & 6,6 & 4,4 \\
\cline { 2 - 5 } & Удосконалений & 2,1 & 5,3 & 3,1 \\
\hline \multirow{2}{*}{ Ннергетична } & Продукційний & 4,6 & 13,2 & 1,2 \\
\cline { 2 - 5 } & Удосконалений & 2,2 & 6,8 & 3,7 \\
\hline \multirow{2}{*}{ Металургійна } & Продукційний & 2,9 & 15,7 & 2,7 \\
\cline { 2 - 5 } & Удосконалений & 0,4 & 9,3 & 11,1 \\
\hline \multirow{2}{*}{ Автомобільна } & Продукційний & 5,2 & 5 & 4,1 \\
\cline { 2 - 5 } & Удосконалений & 3,2 & 4,4 & 3,6 \\
\hline \multirow{2}{*}{ Харчова } & Продукційний & 11,6 & 0 & 8,6 \\
\cline { 2 - 5 } & Удосконалений & 8,1 & 0 & 1,8 \\
\cline { 2 - 5 } & Продукційний & 4,4 & 0,7 & 5,3 \\
\cline { 2 - 5 }
\end{tabular}


Таблиця 4

Рівень точності продукційного методу та удосконаленого методу аналізу фондового ринку акцій

\begin{tabular}{|l|c|c|}
\hline \multicolumn{1}{|c|}{ Галузь } & $\begin{array}{c}\text { Рівень точності } \\
\text { продукційного методу, \% }\end{array}$ & $\begin{array}{c}\text { Рівень точності } \\
\text { удосконаленого методу, \% }\end{array}$ \\
\hline АПК & 72,1 & 85 \\
\hline Логістична & 84,7 & 89,5 \\
\hline Енергетична & 80,1 & 89,8 \\
\hline Нафтопереробна & 77,7 & 87,6 \\
\hline Металургійна & 78,7 & 88,3 \\
\hline Автомобільна & 74,8 & 87 \\
\hline Харчова & 86,3 & 90,4 \\
\hline Усереднений рівень точності, $\%$ & 79,2 & 88,1 \\
\hline
\end{tabular}

та галузевого ризику однієї з 7 галузей. Результати дослідження цих показників представлено в таблиці 2.

Для визначення рівня точності аналізу фондового ринку акцій потрібно визначити відносне відхилення кожного з показників. Для розрахунку відносного відхилення використаємо формулу [9]:

$$
\sigma=\left|\frac{a}{b} * 100\right|-100,
$$

де $a$-дійсне значення,

$b$ - значення, отримане за допомогою одного 3 методів.

Відносне відхилення показників фондового ринку акцій наведене в таблиці 3.

Для розрахунку рівня точності скористаємося формулою [9]:

$$
\Delta=100-(Д+C+\Gamma),
$$

де Д - дохідність, С - ставка дисконтування, Г- галузевий ризик.
Результати розрахунку рівня точності продукційного та удосконаленого методів аналізу фондового ринку акцій занесені до таблиці 4.

Висновки. У статті було запропоновано вдосконалений метод аналізу фондового ринку акцій шляхом використання нечіткої логіки, що базується на продукційному методі аналізу. Дослідження ефективності удосконаленого методу аналізу фондового ринку акцій показало, що цей метод дав змогу врахувати нові показники, що складно формалізуються: рівень доходів населення, рівень інфляції, продуктивність праці, рівень податкових ставок, ліквідність активів, кредитний ризик, демографія інвесторів, стан макроекономіки та інші. У результаті порівняння удосконаленого та продукційного методів аналізу фондового ринку акцій (на основі семи різних галузей) виявлено, що в середньому використання запропонованого методу аналізу фондового ринку акцій збільшує точність такого аналізу на 8,9\%.

\section{Список літератури:}

1. Фондовий ринок. URL: https://uk.wikipedia.org/wiki/Фондовий_ринок (дата звернення: 09.06.2020).

2. Бердникова Т.Б. Оцінка цінних паперів : навчальний посібник. Київ : Наш Формат, 2016.144 с.

3. Руденко В.Г. Інвестиційний аналіз : навчальний посібник. Харків : ЛАБОРАТОРІЯ МІКРО-ЕОМ, 2008. 245 c.

4. Штанько О.Д. Сучасні тенденції функціонування світових фондових ринків. Академічний огляд. 2013. № 2(39). С. 170-176.

5. Савчук Т.О., Ваховський В.М. Аналіз фондового ринку з використанням штучного інтелекту. XLVIII Науково-технічна конференція підрозділів Вінницького національного технічного університету. Вінниця. 2019. С. 756-757. URL: https://conferences.vntu.edu.ua/index.php/all-fitki/index/pages /view/zbirn 2019 (дата звернення: 25.06.2020).

6. Штучний інтелект на фондовому ринку. URL: https://habr.com/ru/company/iticapital/blog/350092/ (дата звернення: 09.07.2020).

7. Savchuk T.O., Pryimak N.V., Assembay A., Zyska T., Junisbekov M., and A. Annabaev. The technology of searching the associative rules while developing the software, Proc. SPIE 10445, Photonics Applications in Astronomy, Communications, Industry, and High Energy Physics Experiments, 2017. doi: 10.1117/12.2280900.

8. Українська фондова біржа. URL: https:/ukrse.com.ua/analitika (дата звернення: 13.07.2020).

9. Романов В.П. Интеллектуальные информационные системы в экономике : учебное пособие. Москва : Издательство «Экзамен», 2013. 496 с. 


\section{Savchuk T.O., Vakhovskyi V.M. IMPROVEMENT OF THE METHOD OF ANALYSIS OF THE STOCK MARKET OF SHARES}

The scientific article considers the most common methods of stock market analysis and identifies their main advantages and disadvantages. The main disadvantage of these methods of stock market analysis can be considered the low level of their analytical accuracy, which makes them inefficient to use. It is determined that fuzzy logic has the potential to improve the production method of stock market analysis.

The scientific article proposed an improved method of stock market analysis, which is based on the production method of stock market analysis using elements of fuzzy logic. This method allows to increase the efficiency of stock market analysis by using indicators that are difficult to formalize, by introducing fuzzy sets, membership functions, linguistic variables, term sets, fuzzy implication and degree of truth, which in turn improves the accuracy of analysis, and also an increases the degree of automation of conflict resolution during the analysis, which rejects the constant need for user intervention and contributes to the formation of sound conclusions about the trend of changes in stock market prices.

The scientific article conducted a study of the effectiveness of the improved method of stock market analysis, which showed that this method allowed to take into account new indicators that are difficult to formalize, including: profitability, inflation rate, productivity, level of tax rates, liquidity of assets, credit risk, investor demography, the state of macroeconomics and others indicators. As a result of comparing the improved and productive methods of stock market analysis (based on seven different industries of stock market analysis) it was found that the use of the proposed improved method of stock market analysis, on average, increases the accuracy of such analysis by $8.9 \%$.

Key words: stock market, fuzzy logic, stock market analysis method, data mining, fuzzy implication. 